\title{
COMPARATIVE STUDIES ON THE SOLUBLE AND PLASMA MEMBRANE ASSOCIATED NITRATE REDUCTASE FROM CUCUMIS SATIVUS L.
}

\author{
GRAŻYNA KŁOBUS, JOLANTA MARCINIAK, JÓZEF BUCZEK \\ Plant Physiology Department, Institute of Botany, \\ Wrocław University, Kanonia 6/8, 50-328 Wocław, Poland
}

(Received: September 2, 1994. Accepted: October 20, 1994)

\begin{abstract}
The biochemical comparison between two forms of nitrate reductase from cucumber roots: the soluble enzyme and the plasma membrane-associated one was made. Soluble nitrate reductase was purified on the blue-Sepharose 4B. The nitrate reductase bound with plasma membranes was isolated from cucumber roots by partition of microsomes in the $6.5 \%$ dextranPEG two phase system. The molecular weight of native enzyme estimated with HPLC was $240 \mathrm{kDa}$ and $114 \mathrm{kDa}$ for the soluble and membrane bounded enzyme, respectively. Temperature induced phase separation in Triton X-114 indicated a huge difference in hydrophobicity of the plasma membrane associated nitrate reductase and soluble form of enzyme. Small differences were observed in partial activities of plasma membrane nitrate reductase and soluble nitrate reductase. Also experiments with polyclonal antiserum raised against the native nitrate reductase showed some differences in the immunological properties of both forms of the nitrate reductase. The above results indicated that in cucumber roots two different forms of the nitrate reductase are present.
\end{abstract}

KEY WORDS: cucumber roots, nitrate reductase, plasma membrane.

\section{INTRODUCTION}

The nitrate reductase (EC 1.6.6.1) catalyzes a rate-limiting step of inorganic nitrogen assimilation in green plants and fungi (Beevers and Hageman 1980, Guerrero et al. 1981). Soluble nitrate reductase has been purified and well characterized in many plants. This multiredox center enzyme has been demonstrated to be a homodimer. Each subunit of the nitrate reductase contains FAD, cyt b557 and molybdo-pterin as cofactor, and exhibits a number of partial activities (Hewitt and Notton 1980, Solomonson and Barber 1990). Experiments with limited proteolysis of the nitrate reductase protein have explained the cofactor requirements for particular activities (Notton et al. 1988). Small part of enzyme containing both FAD and NADH-binding sites is responsible for a diaphorase activity which comprises NADH:ferricyanide, NADH:cyt.c and NADH:dichlorophenolindophenol reductase activities. A nitrate reducing (FMNH:NR and MVH:NR) activity of the enzyme is connected with a large part of protein containing an active Mo center. In higher plant cells a cytosolic localization of nitrate reductase is generally accepted. Recently, a second form of the enzyme connected with plasma membranes in alga cells (Tischner et al 1989, Jones and Morel 1989, Stor et al 1993) and barley roots (Ward et al. 1989) was described. In presented paper we proved that the plasma membrane form of the nitrate reductase, different from the soluble one, is present in cucumber roots.

\section{MATERIAL AND METHODS}

\section{Plant material.}

Cucumber (Cucumis sativus L. var. Wiskonsin) seeds were germinated $48 \mathrm{~h}$ in darkness at $25^{\circ} \mathrm{C}$. Seedlings were transferred to the nutrient solution and cultivated, as described previously (Kłobus 1990).

\section{Isolation of plasma membranes.}

Cucumber roots were homogenized in a cold $25 \mathrm{mM}$ TRISMES (pH 7.5), $330 \mathrm{mM}$ sucrose, $0.2 \%$ BSA, 3 mM EDTA$\mathrm{Na} 2,1 \mathrm{mM}$ DTT, $1 \mathrm{mM}$ PMSF and $0.5 \%$ (w/v) PVPP. The homogenate was filtrated through Miracloth and microsomes $(15.000-100.000 \mathrm{~g})$ were pelleted, resuspended in $5 \mathrm{mM} \mathrm{K}-$ phosphate ( $\mathrm{pH} \mathrm{7.8)}, 5 \mathrm{mM} \mathrm{KCl}, 330 \mathrm{mM}$ sucrose, $0.1 \mathrm{mM}$ EDTA and $1 \mathrm{mM}$ DTT, and used for the plasma membrane isolation in a two phase system, as described earlier (Kłobus 1993).

\section{Temperature-induced phase separation with Triton X-114.}

Plasma membrane proteins and proteins of the soluble fraction (supernatant obtained after centrifugation of homogenate at $100.000 \mathrm{~g}$ ) were fractioned according to Pryde and Philips (1986). Before fractionation the plasma membranes were washed with $10 \mathrm{mM}$ Tris- $\mathrm{HCl}(\mathrm{pH}$ 7.8) containing $0.15 \mathrm{M}$ $\mathrm{NaCl}$ and resuspended in the same buffer. The final concentration of protein in both, plasma membrane suspension and soluble fraction was about $4 \mathrm{mg}$ per $\mathrm{cm}^{3}$. Solutions were cooled to $0^{\circ} \mathrm{C}$ and Triton $\mathrm{X}-114$ was added to the final concentration $2 \%(\mathrm{w} / \mathrm{v})$. Solubilized membranes and the soluble 
TABLE 1. Distribution of the nitrate reductase and marker enzyme activities in the soluble, microsome and plasma membrane fractions isolated from cucumber roots.

\begin{tabular}{lccc}
\hline \multicolumn{1}{c}{ Enzyme activities } & $\begin{array}{c}\text { Soluble } \\
\text { fraction }\end{array}$ & Microsomes & $\begin{array}{c}\text { Plasma } \\
\text { membranes }\end{array}$ \\
\hline nitrate reductase $^{\mathrm{a}}$ & $84.3+1.3$ & $86.1+1.0$ & $99.97+1.22$ \\
${\text { cyt. c } \text { oxidase }^{\mathrm{b}}}^{\text {nitrite reductase }}$ & not determined & $25.0+0.1$ & $\mathrm{nd}$ \\
$\mathrm{NADH}^{\mathrm{a}}$-cyt.c reductase & $54.2 \pm 0.9$ & $12.8 \pm 0.005$ & $\mathrm{nd}$ \\
antimycin sensitive $^{\mathrm{b}}$ & not determined & $1.8+0.03$ & $104.1+3.22$ \\
$\mathrm{VO}_{3}-$ ATPase $^{\mathrm{c}}$ & not determined & $38.4+0.9$ & $0.08+0.012$ \\
$\mathrm{NO}_{2}-$ ATPase $^{\mathrm{c}}$ & not determined & $2.6+0.03$ & nd \\
PEP-carboxylase $^{\mathrm{d}}$ & $1.2+0.1$ & $0.2+0.005$ & \\
\hline
\end{tabular}

\footnotetext{
* not detected

a nol $\mathrm{NO}_{2}^{-} \times \mathrm{mg}^{-1}$ protein $\times \mathrm{h}^{-1}$

${ }^{b}$ nmol cyt.c $\times \mathrm{mg}^{-1}$ protein $\times \mathrm{min}^{-1}$

${ }^{c} \mu \mathrm{mol} \mathrm{P} \times \mathrm{mg}^{-1}$ protein $\times \mathrm{h}^{-1}$

d ${ }_{\text {nmol PEP }} \times \mathrm{mg}^{-1}$ protein $\times \mathrm{h}^{-1}$
}

Fractions were isolated as described in Material and Methods. Presented values are averages with SE of three replications.

fraction were placed on ice for $5 \mathrm{~min}$ and than centrifuged 30 $\mathrm{min}$ at $58000 \mathrm{~g}$ to precipitate phospholipids. Supernatants were layered onto $2 \mathrm{~cm}^{3}$ of $0.25 \mathrm{M}$ sucrose in $10 \mathrm{mM}$ Tris$\mathrm{HCl}(\mathrm{pH} \mathrm{7.8)}$ with $0.15 \mathrm{M} \mathrm{NaCl}$ and $0.06 \%$ Triton X-114, incubated $5 \mathrm{~min}$ at $30^{\circ}$ and then centrifuged. Two different fractions were collected after centrifugation: an aqueous phase which was formed above the sucrose cushion and a detergent-rich phase formed under the cushion. All obtained phases: phospholipid-rich, detergent-rich and aqueous phase were repurified.

\section{Antigen and antibody production.}

Purification of the nitrate reductase and production of polyclonal anti-NR was made as described previously (Marciniak et al. 1994).

\section{Electrophoresis, western and dot blots.}

Native gels ( $7 \%$ polyacrylamide) of denatured plasma membrane and soluble proteins were developed at $4^{\circ} \mathrm{C}$ by modified method of Laemmli (1970). Western blots of gels were undertaken as described by Sambrook et al.(1989). Both, the soluble and plasma membrane-bound nitrate reductase were detected on the nitrocelullose with goat polyclonal antibodies raised against cucumber root soluble nitrate reductase (Marciniak et al. 1994), in combination with a horseradish peroxidase (HRP-conjugated anti-goat $\mathrm{IgG}$, Sigma). Proteins of phospholipid-rich, detergent-rich and aquous fractions obtained after temperature-induced phase separation in Triton X-114 were dot-blotted onto nitrocelullose strips and dried for $30 \mathrm{~min}$ in the room temperature. Then strips were incubated with antibody and the nitrate reductase proteins were visualized on membranes as described above.

\section{Gel filtration.}

To determine the molecular mass of soluble nitrate reductase TSK $3000 \mathrm{SW}$ column connected to HPLC system was used. Liofilized proteins obtained after purification of the soluble enzyme on a blue-dextran-Sepharose 4B (Marciniak et.al 1994), resolved in $50 \mathrm{mM}$ Tris- $\mathrm{HCl} \mathrm{pH} 6.8$ and loaded onto column, were eluted with the same buffer containing 100 $\mathrm{mM} \mathrm{KCl}$, at the flow rate $0.8 \mathrm{~cm}^{3} \times \mathrm{min}^{-1}$. The absorbance of eluent at $280 \mathrm{~nm}$ was measured. The molecular mass of enzyme was calculated from the calibration curve prepared for the catalase $(250 \mathrm{kDa})$, alcohol dehydrogenase (150 kDa) and BSA $(66.3 \mathrm{kDa})$.

\section{Enzyme assay.}

Specific ATPase activities were determined according to Gallagher and Leonard (1982). The nitrate reductase activity was measured as Ward et al. (1989) described. Determination of partial activities (FMNH-NR, MVH-NR and diaphorase activity) was made according to Sherrard and Dalling (1979).

Protein was measured by the method of Bradford (1976), as modified by Ward et al (1989).

\section{RESULTS}

Aqueous two-phase partitioning of cucumber root microsomes used for the isolation of plasma membranes resulted in a very high purity of obtained fraction (Table 1). The nitrate reductase activity was detected in cytosol, microsomes and highly purified plasma membrane fractions of root cells (Table 1). Polyclonal antibodies raised against the purified native nitrate reductase isolated from cucumber roots recognized the nitrate reductase of all: soluble, microsome and plasma membrane fractions. (Fig. 1). In spite of the positive immunological reaction, anti-NR included into reaction medium did not inhibit the activity of the nitrate reductase in plasma membrane fraction (Table 2). Alternatively, they distinctly diminished the nitrate reductase activity in soluble fraction.

TABLE 2. The effect of anti-NR on the activity of the nitrate reductase in plasma membrane and soluble fraction of cucumber root cells.

\begin{tabular}{ccc}
\hline \multirow{2}{*}{$\begin{array}{c}\text { Dilution } \\
\text { of anti-NR }\end{array}$} & Soluble NR & Plasma membrane NR \\
\cline { 2 - 3 } & $\mathrm{nmol}^{-1} \mathrm{NO}_{2} \times \mathrm{mg}^{-1}$ protein $\mathrm{x} \mathrm{h}^{-1}$ \\
\hline $0 / 0$ & 114.30 & 125.38 \\
$1 / 100$ & 22.01 & 124.76 \\
$1 / 10$ & 0 & 124.79
\end{tabular}

The nitrate reductase was assayed in a soluble fraction purified with dextran-blue Sepharose $4 \mathrm{~B}$ and plasma membranes collected from upper phase of $6.5 \%$ two-phase system. 
A

1

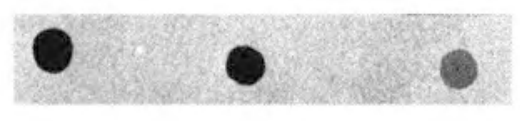

2

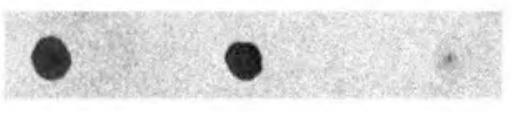

3

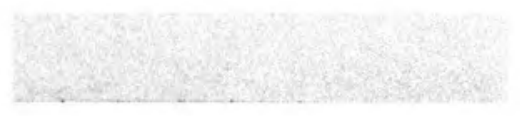

A

B

C

D

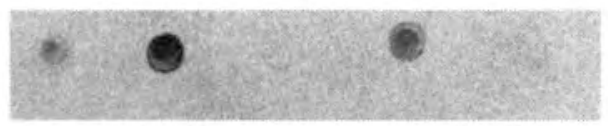

Fig. 1. Reactivity of anti-NR serum to the soluble (cytosolic) fraction (A), microsomes (B) and plasma membranes (C) isolated from cucumber roots.

A soluble fraction and microsomes were obtained after subsequent centrifugation of cucumber root homogenate at 20000 and $100000 \times \mathrm{g}$, as described in Material and Methods. Plasma membranes were collected from upper phase of $6.5 \%$ two-phase system, as described earlier (Kłobus et al. 1994). $6 \mu \mathrm{g}$ (row 1) or $3 \mu \mathrm{g}$ (row 2) of protein were dot-blotted onto nitrocelullose and probed with anti-NR serum or with pre-immune serum (row 3, $6 \mu \mathrm{g}$ of protein were used).

Fig. 2. The binding of anti-NR serum to microsomes and plasma membranes after Triton X-100 treatment.

Microsomes and plasma membranes were incubated 15 min with $0.1 \%$ of Triton X100 and centrifuged at $50000 \times \mathrm{g}$ (microsomes) or $100000 \times \mathrm{g}$ (plasma membranes) for $30 \mathrm{~min}$. Microsomes (A) or plasma membranes (C) suspensions and supernatants obtained after centrifugation of both, microsomes (B) and plasma membranes (D) dot-blotted onto nitrocelullose (about $0.2 \mu \mathrm{g}$ ) were probed with anti-NR serum.
The intensity of antibody cross-reaction was much lower with the membrane pellet than with supernatant obtained after Triton X-100 treatment of microsomes (Fig. 2 A). When the plasma membranes were incubated with Triton X-100, only slight immunological reaction with supernatant fraction was observed (Fig. 2 B). Above results indicated that detergent released only a small part of the nitrate reductase from plasma membranes.

The molecular masses of a native enzyme associated with plasma membrane fraction, estimated by gel electrophoresis was $114 \mathrm{kDa}$ (Fig. 3a), whereas the molecular mass of native nitrate reductase estimated by gel filtration on Ultrapac TSK G 2000 column was $240 \mathrm{kDa}$ (Fig. 3b).

Temperature induced phase separation in Triton X-114 indicated a huge difference in a hydrophobicity of the plasma membrane-bound nitrate reductase and soluble form of enzyme (Table 3 ). The highest nitrate reductase activity of plasma membranes was found in a phospholipid rich fraction. It is worth to mention, that distribution of the nitrate reductase in fractions obtained after Triton X-114 separation of plasma membrane proteins was tightly correlated with the activity of vanadate-sensitive ATPase. Distribution of the nitrate reductase in fractions obtained after temperature-induced Triton X-114 partition of the soluble part of root cells was totally different. The highest activity was found in an aqueous phase of the system, whereas phospholipid rich phase did not posses any nitrate reductase activity. These findings were confirmed by dot-blot immunoassays (Fig. 4).

The nitrate reductase of soluble and plasma membrane fractions exhibited all partial activities (Table 4). Additionally, $\mathrm{MVH} / \mathrm{FMNH}-\mathrm{NO}_{3}{ }^{-}$activity of plasma membrane-bounded nitrate reductase was almost as high as $\mathrm{NADH}-\mathrm{NO}_{3}{ }^{-}$activity, whereas MVH and FMNH-dependent nitrate reduction in soluble fraction were only about $40 \%$ of NADH - dependent $\mathrm{NO}_{3}{ }^{-}$reduction.
Table 3. Temperature-induced phase separation of soluble and plasma membrane fraction in Triton X-114.

\begin{tabular}{lccc}
\hline Subcellular fraction & \multicolumn{3}{c}{ Temperature-induced Triton X-114 fraction } \\
\cline { 2 - 4 } & $\begin{array}{c}\text { phospholipid } \\
\text { rich }\end{array}$ & $\begin{array}{c}\text { detergent } \\
\text { rich }\end{array}$ & aqueous \\
\hline soluble fraction & $0.00^{1}$ & 0.001 & 65.41 \\
\hline plasma membrane & $49.08^{1}$ & 14.31 & $0.00^{1}$ \\
& $12.97^{2}$ & $1.33^{2}$ & $0.95^{2}$ \\
\hline
\end{tabular}

nitrate reductase activity in $\mathrm{nmol} \mathrm{NO}_{2} \times \mathrm{cm}^{-3}$ fraction

${ }^{2}$ ATPase activity in $\mu \mathrm{mol} \mathrm{P}_{\mathrm{i}} \times \mathrm{mg}^{-1}$ fraction

Presented values are averages of five replications.

\section{DISCUSSION}

Besides soluble nitrate reductase, a plasma membranebound form of the enzyme in cucumber root cells was detected. The activity of nitrate reductase detected in plasma membranes was not due to the cytosol contamination, which could be trapped inside vesicles during preparation, as Askerlund at al. (1991) have suggested. It was proved by the distribution of marker enzyme activities (Table 1) and by the fact, that Triton X-100 treatment released only a slight nitrate reductase activity from plasma membrane vesicles (Fig. 2). Temperature-induced separation of plasma membrane and cytoplasm proteins in Triton X-114 (Table 3) followed with dot blot probes (Fig. 4) confirmed this assumption. After Triton $\mathrm{X}-114$ separation of plasma membrane proteins, the nitrate reductase activity was recovered together with the vanadatesensitive ATPase (a specific marker for plasma membranes) in phospholipid-rich fraction, whereas after fractionation of cytosolic proteins the activity of nitrate reductase was detected only in an aquous phase. Varied separation of plasma membrane and cytosolic proteins in Triton X-114 indicates 

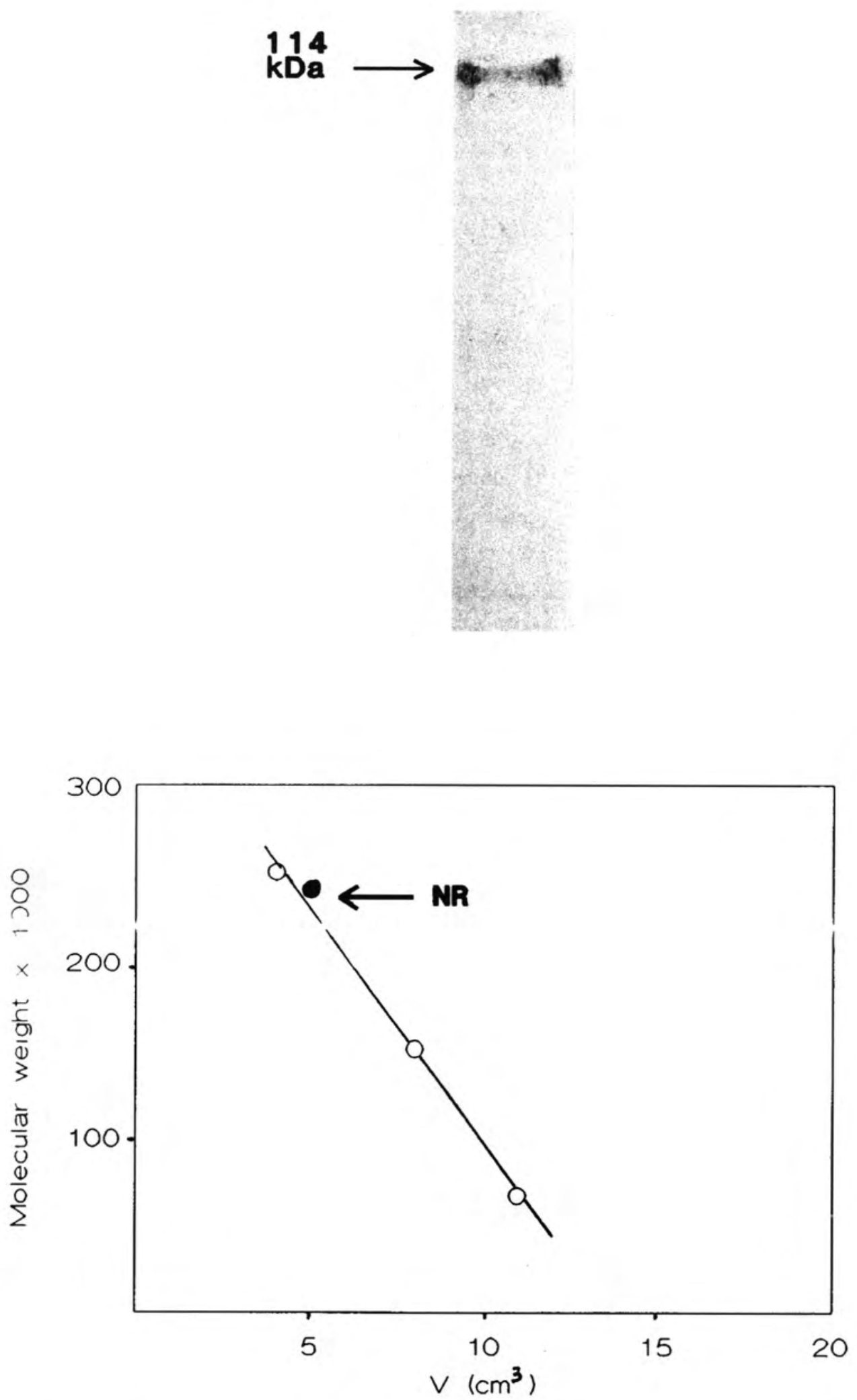

Fig. 3. Determination of a native molecular mass of the soluble or plasma membrane-bounded nitrate reductase.

A. $50 \mu \mathrm{g}$ of plasma membrane proteins were denatured $5 \mathrm{~min}$. in $80^{\circ} \mathrm{C}$ and loaded onto $7.5 \%$ PAGE. After 5 hours of electrophoresis proteins were blotted onto nitrocelullose strep and probed with anti-NR serum.

B. $100 \mu \mathrm{g}$ of liofilized soluble nitrate reductase prepared from cucumber roots were resuspended in $50 \mu \mathrm{l}$ of $50 \mathrm{mM}$ Tris-Mes, pH 6.8 and loaded onto Ultrapac TSK G 2000 column $(0.45 \times 30 \mathrm{~cm})$ equlibrated with this same buffer. Proteins were eluted with $100 \mathrm{mM} \mathrm{KCl}$ in $50 \mathrm{mM}$ Tris-Mes, $\mathrm{pH}$ 6.8. Calculations of molecular masses were made from a calibration curve. 
(A)

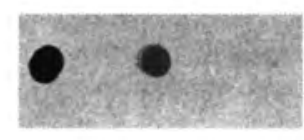

(B)

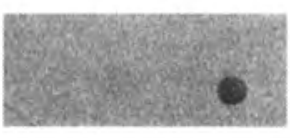

Fig. 4. The binding of anti-NR serum to fractions obtained after temperature-induced Triton X-114 treatment of soluble and plasma membrane fraction.

Fractions obtained after temperature-induced partition of plasma membrane (A) and soluble (B) fractions in Triton X-114 were dot-blotted onto nitrocelullose and probed with anti-NR serum as described in Material and Methods.

1 - phospholipid-rich fraction, 2 - detergent-rich fraction, 3 - aqueous fraction

Table 4. Partial activities of the soluble and plasma membrane-bound nitrate reductase isolated from cucumber roots.

\begin{tabular}{lcc}
\hline \multicolumn{1}{c}{ Partial activities of NR } & Soluble NR & Plasma membrane NR \\
\hline NADH - NR & $126.95^{1}$ & 152.341 \\
MVH - NR & $52.01^{1}$ & $142.17^{1}$ \\
FMNH - NR & $50.03^{1}$ & $134.76^{1}$ \\
NADH/cyt.c - NR & $40.31^{2}$ & $49.38^{2}$ \\
\hline
\end{tabular}

${ }_{2}^{1} \mathrm{nmol} \mathrm{NO}_{2}^{-} \times \mathrm{mg}_{-1}^{-1}$ protein $\mathrm{x} \mathrm{h}^{-1}$

${ }^{2}$ nmol cyt.c $\times \mathrm{mg}^{-1}$ protein $x \mathrm{~min}^{-1}$

Partial activities of the nitrate reductase were assayed in a soluble fraction purificated with dextran-blue Sepharose 4B and plasma membranes collected from upper phase of $6.5 \%$ two-phase system.

the differences in their hydrophobicity. According to Pryde et al. (1986) a phospholipid-rich fraction contains only highly hydrophobic proteins, whereas hydrofilic proteins are collected in an aquous fraction. Stöhr et al (1993) used successfully similar system to eliminate a cytoplasm contaminations of plasma membrane-bound proteins in Chlorella saccharophilia cells.

Polyclonal antiserum generated against the soluble nitrate reductase purified on blue-Sepharose exhibited a high specificity to the denatured plasma membrane proteins (Westernblot probes). Antibodies recognized also the native form of plasma membrane nitrate reductase (dot-blot assay) but did not inhibit the activity of enzyme, indicating that epitopes recognized were not in or near the catalytic sites. Such observations suggest that cytosolic nitrate reductase and plasma membrane form of the enzyme share functional and structural similarities, but can be divergent in an amino acid sequence. Also small structural modification of plasma membrane nitrate reductase due to build up of the enzyme protein in the membrane cannot be ruled out.

The soluble nitrate reductase from different tissues of higher plants is a homodimer with molecular mass ranging between 200 to $270 \mathrm{kDa}$ (Nagakawa et al. 1985, Campbell 1988). Similar native mass was estimated in our experiments by a gel filtration for cucumber root soluble nitrate reductase. Plasma membrane bounded form of enzyme showed only one band at $114 \mathrm{kDa}$ after gel electrophoresis without SDS followed with Western-blot. This is similar to a subunit size of the nitrate reductase, reported in the literature (for review see Solomonson and Barber 1990, Buczek and Marciniak 1990) and points that the plasma membrane associated enzyme is a monomer. It is worth to notice, that each subunit of the nitrate reductase posses all catalytic properties of the enzyme and can function independently.
There were also small differences in partial activities of the plasma membrane and soluble nitrate reductase. Although, the enzyme associated with plasma membranes exhibits all partial activities, its activity determined with $\mathrm{MVH}$ or FMNH as an electron donor was almost equal as NADH-NR activity. On the other hand, the soluble nitrate reductase used preferentially NADH as a reducer.

To summarize, the plasma membrane bounded nitrate reductase detected in cucumber roots differs from a soluble form of the enzyme in its hydrophobicity, immunological properties and molecular mass. Future experiments are needed to elucidate the physiological function of the membrane associated enzyme.

\section{List of abbreviations:}

BSA - bovine serum albumin,

DTT - dithiotreitol,

EDTA - ethylenediamine tetraacetic acid,

NR - nitrate reductase,

PVPP - polyvinylpolypyrrolidine,

PMSF - phenylmetanesulfonyl fluoride,

SDS - sodium dodecyl sulfate,

\section{LITERATURE CITED}

ASKERLUND P. LAURENT P., NAGAKAWA H., KADER J-C. 1991. NADH-ferricyanide reductase of leaf plasma membranes. Plant Physiol. 95: 6-13

BEEVERS L., HAGEMAN R.H. 1980. Nitrate and nitrite reduction. In: The Biochemistry of Plants. Miflin B.J. ed., New York: Academic Press, Vol.5: 115-168 
BRADFORD M.M. 1976. A rapid and sensitive method for the quantitation of microgram quantities of protein utilizing the principle of rotein-dye binding. Anal. Biochem. 72: 278-293

BUCZEK J., MARCINIAK J. 1990. Reduktaza azotanowa i reduktaza azotynowa -kluczowe enzymy asymilacji azotanów w roślinach wyższych. Wiadomości Botaniczne 34 (1): 19-23

CAMPBELL W.H. 1988. Nitrate reductase and its role in nitrate assimilation in plants. Physiol. Plant. 74: 214-219

GALLAGHER S.R., LEONARD R.T. 1982. Effect of vanadate, molybdate and azide on membrane associated and soluble phosphatase activities of corn roots. Plant Physiol. 70: 1335-1340

GUERRERO M.G., VEGA J.M., LOSADA M. 1981. The assimilatory nitrate-reducing system and its regulation. Ann. Rev. Plant Physiol. 70: $410-413$

HEWITT E.J., NOTTON B.A. 1980. Nitrate reductase system in eucaryota and procaryota organisms. In: Molybdenum and Molybdenum containing enzymes. Coughlan M. ed. Oxford, Pergamon Press, pp: 273-325

JONES G.J., MOREL F.M.M. 1989. Plasmalemma redox activity in the diatom Thalassiosira. A possible role for nitrate reductase. Plant Physiol. 87: 143-147

KŁOBUS G. 1990. Correlation between $\mathrm{NO}_{3}{ }^{-}$absorption and plasmalemma associated ATPase activity in Cucumis sativus L. roots. Acta Physiol. Plant. 12(3): 225-231

KŁOBUS G. 1993.The role of membrane-bound activities in the nitrate transport into sealed plasma membrane vesicles from Cucumis sativus L. roots. Proceedings of 4th International Symposium „Structure and Function of Roots", Kluver, in press

LAEMMLI U.K. 1970. Cleavage of structural proteins during the assembly of the head of bacteriophage T4. Nature 227: 680-689
MARCINIAK J., KŁOBUS G., BUCZEK J. 1994. Immunological comparison of the nitrate reductase from different cucumber tissues. In press

NAGAKAWA H., YAMAGISHI K., YAMASHITA N., SATO T., OGURA N., OAKS A. 1986. Immunological characterization of nitrate reductase in different tissue of spinach seedlings. Plant cell Physiol. 27(4): 627-633

NOTTON B.A., BARBER M.J., FIDO R.J., WHITFORD P.N., SOLOMONSON L.P. 1988. Immunological comparison of spinach and Chlorella nitrate reductase. Phytochemistry 27: 1965-1968

PRYDE J.G., PHILIPS J.H. 1986. Fractionation of membrane proteins by temperature-induced phase separation in Triton X-114. Biochem. J. 233: 525-533

SAMBROOK J., FRITSCH E.F., MANIATIS T. 1989. Molecular cloning, a laboratory manual. 2nd edition. Cold Spring Harbor Laboratory press, cold Spring Harbor, New York

SHERRARD J.H., DALLING M.J. 1979. In vitro stability of nitrate reductase from wheat leaves. I. Stability of highly purified enzyme and its component activities. Plant Physiol. 63: 346-353

SOLOMONSON L.P., BARBER M.J. 1990. Assimilatory nitrate reductase: functional properties and regulation. Ann. Rev. Plant Physiol. 41: 225-253

STÖR C., TISCHNER R., WARD M.R. 1993. Characterization of the plasma-membrane-bound nitrate reductase in Chlorella saccharophilia (Kruger) Nadson. Planta, 191: 79-85

TISCHNER R. WARD M.R., HUFFAKER R.C. 1989. Evidence for a plasma- membrane-bound nitrate reductase involved in nitrate uptake of Chlorella sorokiniana. Planta 178: 19-24

WARD M.R., GRIMES H.D., HUFFAKER R.C. 1989. Latent nitrate reductase activity associated with the plasma membrane of corn roots. Planta 177: 470-475.

\section{PORÓWNAWCZE BADANIA NAD ROZPUSZCZALNĄ I PLAZMALEMMOWA FORMĄ REDUKTAZY AZOTANOWEJ W KOMÓRKACH KORZENIA CUCUMIS SATIVUS L.}

\section{STRESZCZENIE}

W komórkach korzeni ogórka wykazano obecność dwóch form reduktazy azotanowej różniących się lokalizacją subkomórkową, właściwościami biochemicznymi i immunologicznymi. Ciężar cząsteczkowy reduktazy azotanowej występującej w cytoplazmie komórek (frakcja rozpuszczalna) wynosił $240 \mathrm{kDa}$ podczas gdy ciężar enzymu związanego z plazmalemmą wynosił $114 \mathrm{kDa}$. Indukowany temperaturą rozdział białek cytoplazmatycznych bądź plazmalemmowych w Triton X-114 wykazał różną hydrofobowość reduktazy azotanowej poszczególnych frakcji komórki. Wykazano także różnice w cząstkowych aktywnościach reduktazy cytoplazmatycznej i plazmalemmowej. Doświadczenia z zastosowniem poliklonalnych przeciwciał uzyskanych przeciwko rozpuszczalnej reduktazie azotanowej dowiodły różnic we właściwościach immunologicznych obydwu form enzymu.

SŁOWA KLUCZOWE: korzenie ogórków, reduktaza azotanowa, plazmolemma. 